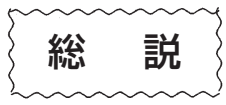

\title{
粘液胞子虫性やせ病
}

\author{
柳田哲矢*
}

（2017年 4 月28日受付）

\section{Myxosporean Emaciation Disease}

\author{
Tetsuya Yanagida* \\ Laboratory of Veterinary Parasitology, Joint Faculty of Veterinary Medicine, \\ Yamaguchi University, Yamaguchi 753-8515, Japan
}

(Received April 28, 2017)

\begin{abstract}
Myxosporean emaciation disease is caused by the enteric myxosporeans Enteromyxum leei and Sphaerospora fugu (syn. Leptotheca fugu). It emerged in the aquaculture of tiger puffer since mid-1990s in Japan. Thus far, more than 50 marine fishes have been reported as susceptible to $E$. leei in Europe and East Asia. As it has a wide host range and is feasible to transmit directly from fish to fish, $E$. leei is considered to be one of the most devastating parasites in warm water seawater aquacultures. Regardless of its economic impact, neither effective treatment nor preventive measure for the disease has been established until now. To control this disease, further studies are needed for better understanding of the biology of the parasites and of the host-parasite interaction.
\end{abstract}

歴

史

1996年から，九州の養殖トラフグに著しいやせ症状を 特徴とする疾病の発生が確認されるようになった。病魚 は，頭骨が張り出して目が落ちくぼむほどのやせ症状を 呈し，最終的に死亡した（Fig. 1A）。病魚の腸管上皮組 織内から新種の粘液胞子虫 Leptotheca fugu と未同定種 のMyxidium sp. が発見され, 病理組織学的観察から本疾 病の原因とされた（Tin Tun et al., 2002）。粘液胞子虫の 種同定には胞子の形態観察が必要だが, Myxidium sp. は トラフグ内で胞子を形成しないために種同定がなされな かった。後に, 実験的にMyxidium sp. を感染させたマダ イから得られた胞子の形態観察と, 18S リボソーム RNA 遺伝子を対象とした遺伝子解析の結果に基づき，本種は Enteromyxum leei に同定された（Yanagida et al., 2004）。 また, 後にL.fuguはSphaerospora属に転属された (Gunter and Adlard, 2010)。

E.leei によるやせ病については, 1990年代初頭にキプ

\footnotetext{
山口大学共同獣医学部獣医寄生虫学教室

* Corresponding author

E-mail: yanagi-t@yamaguchi-u.ac.jp
}

ロス共和国の養殖ヨーロッパヘダイ Sparus aurata で発 生したのが初報告である。その後, E. leei は養殖魚や水 族館の飼育魚から続々と報告され，現在までに50種を超

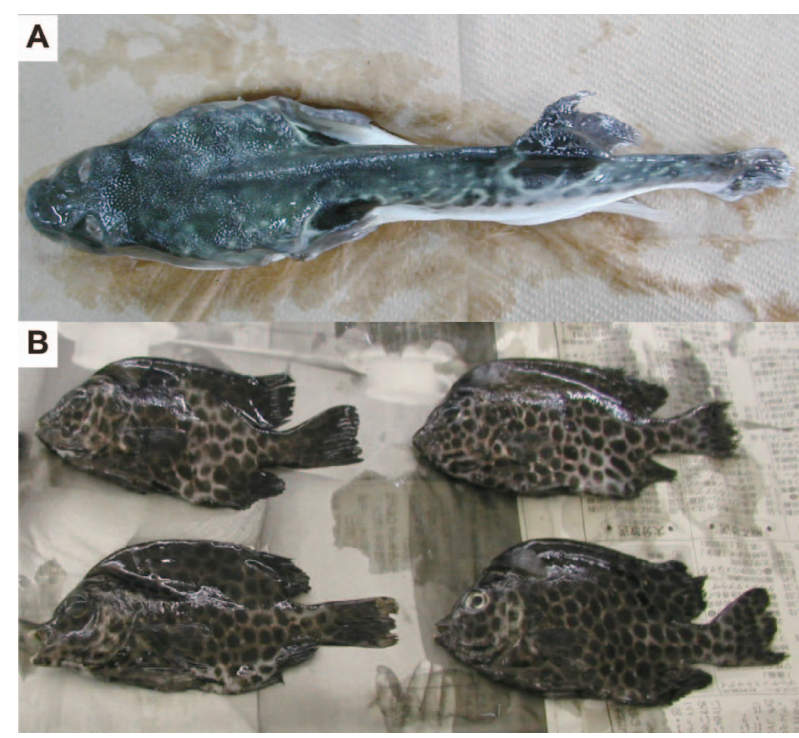

Fig. 1. Severely emaciated tiger puffer $(A)$ and spotted knifejaw (B) infected with Enteromyxum leei. 
える海産魚に感染することが知られている。地中海，力 ナリア諸島沿岸から紅海まで広く分布し，経済的に大き な被害をもたらしている（Sitjá-Bobadilla and Palenzuela, 2012)。近年では, 韓国の養殖ヒラメとターボット（イ シビラメ) Scophthalmus maximus からも報告がある (Sekiya et al., 2016)。日本国内では，養殖ヒラメ，マダ イ、イシガキダイおよびヤイトハタでE. leeiによるやせ 病が報告されている（Yasuda et al., 2005; Yanagida et al., 2008 ; 知名ら, 2013)。また, 実験的にはクサフグ, クマノミ, カクレクマノミにも感染することが知られて いる (Yokoyama and Shirakashi, 2007; Yokoyama et al., 2009）。これまでに, 沖縄県, 九州各県, 四国, 和歌山 県, 福井県などで本疾病の発生が確認されている。根本 的な対策は確立されておらず，現在でも各地の養殖場に おいて発生し，被害をもたらしている。

\section{病原体・生活環}

国内で本疾病の原因となるのは，双殼目の粘液胞子虫 E. leei とS.fuguである。ヨーロッパでは, ターボットに 同様の病気を引き起こす Enteromyxum scophthalmi も知 られているが，日本国内での報告はない。E.leei の胞子 は緩やかな三日月型で，長さ $13.9-19.1 \mu \mathrm{m} ，$ 幅 5.6$11.0 \mu \mathrm{m}, \quad 2$ 個の極囊が八の字型に配列している。ただ し，トラフグやヒラメではほとんど胞子がみられず，観 察されるのは栄養体である（Fig. $2 \mathrm{~A}$ and B)。一方の $S$. fugu の胞子は丸みを帯びた台形で，長さが 8.3-9.5 $\mu \mathrm{m}$,

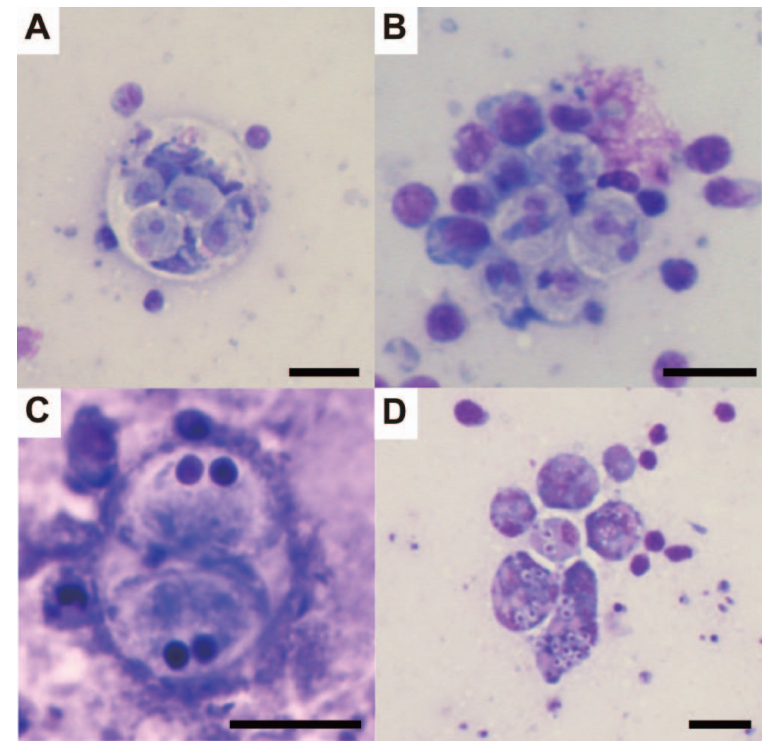

Fig. 2. Developmental stages of Enteromyxum leei and Sphaerospora fugu in the intestinal imprints stained with Diff-Quik. Bars $=10 \mu \mathrm{m}$. (A) and (B) Presporogonic trophozoites of $E$. leei from tiger puffer. (C) Spores of Sphaerospora fugu in the disporoblast. (D) Presporogonic trophozoites of $S$. fugu hyperinfected with microsporidian.
幅 13.0-15.0 $\mu \mathrm{m}, 2$ 個の極囊は球形である（Fig. 2C）。 両種とも腸管上皮組織内に寄生して上皮の変性や剥離を 引き起こすが, S. fugu の方が病変の程度は比較的軽度で ある。E.leeiでは，魚種によって胆囊，胆管，脾臟，鰓 からも虫体が見つかっている (Alvarez-Pellitero et al., 2008 ; 知名ら，2013）。虫体は確認されていないものの, ヒラメとターボットでは肝臓, 胆囊, 腎臓, 膀胱から特 異的 PCR 法で検出されたとの報告もある (Sekiya et al., 2016）。罹患魚が短期間でやせる機構は解明されていな いが，腸管上皮組織が障害を受けることによる浸透圧調 節障害や栄養障害，食欲不振，免疫応答による基礎代謝 の増加, 胆管閉塞による肝臓障害などが関わっていると 考えられている (Ishimatsu et al., 2007; Sitjá-Bobadilla and Palenzuela, 2012 ; 知名, 2013$)$ 。

粘液胞子虫は魚類と環形動物を宿主とする二相性生活 環を持つとされるが, E. leei とS. fugu の生活環は不明で ある。ただし， E. leei は感染魚腸管の経口投与，感染魚 との同居，感染魚飼育排水での飼育によって魚から魚へ 直接伝播することが実験的に証明されている。（Yasuda et al., 2002, 2005; Yanagida et al., 2004)。そのため, 養 殖場内で急速に伝播する。なお，胞子を形成しないトラ フグにおいても実験感染が成立することから，胞子形成 前の栄養体が感染ステージになっていると考えられる。 栄養体は，海水中で24時間は感染性を保つことが示され ている (Yokoyama et al., 2009)。E. leei の宿主範囲は非 常に広く，上述したように50種以上の海産魚から報告さ れている。また，実験的にはゼブラフィッシュなどの淡 水魚にも感染する (Sitjá-Bobadilla and Palenzuela, 2012）。ただし，魚種によって感受性は異なり，ヨーロッ パヘダイやヨーロピアンシーバス Dicentrarchus labrax では比較的症状が軽いのに対し，シャープスナウトシー ブリーム Diplodus puntazzo では被害が大きいとされる (Sitjá-Bobadilla and Palenzuela, 2012)。トラフグやヒラ メについては，本来の宿主ではないためにE. leei が胞子 形成に進むことができず，増員増殖を繰り返すことで寄 生強度が高まるのかもしれない。なお，異なる魚種間で も実験感染が成立することから（Yanagida et al., 2004; Yasuda et al., 2005)，養殖場で魚種をまたいだ伝播が起 こることも想定される。一方，S. fuguはトラフグからの み報告されている。実験感染が成立しないことから， S. fugu の感染環には交互宿主が必要と推察されるが, 詳細 は不明である。

トラフグにおけるE. leei のやせ病発生には季節性があ り，一般的に高水温期に発生が多く，低水温期には収ま る傾向がある。実験的には，E.leei の魚体内に打ける発 育・増殖は水温 $15^{\circ} \mathrm{C}$ 以下で抑制されるものの, $10^{\circ} \mathrm{C}$ で も生存することが示されている (Yanagida et al., 2006)。 そのため, 潜伏感染している越年魚が, 翌年の種苗への 
感染源となりうる。一方, ヤイトハ夕では水温が $21^{\circ} \mathrm{C}-$ $26^{\circ} \mathrm{C}$ の時期に発生が多く, $26^{\circ} \mathrm{C}$ を越えると収束した (知名ら, 2013)。その後水温が低下しても再発しなかっ たことから, 高温処理によって本疾病を治療できる可能 性が示された。しかしながら，養殖トラフグにおいては 水温が $26^{\circ} \mathrm{C}$ を越える高水温期にも本疾病が発生し， $E$. leeiの感染も確認されている（堅田ら，2015）。加温処理 $\left(30^{\circ} \mathrm{C}\right)$ によるE. leei 感染への影響をヤイトハ夕, カク レクマノミ, トラフグで調べたところ，前 2 種では治療 効果があったが，トラフグでは治療効果が見られず，未 感染魚へ伝播した（横山，私信）。以上の結果から，E leei の感染に水温が与える影響には魚種ごとに違いがあ ることが示された。S.fuguについては，明確な季節性が あるという報告はない。実験感染が成立しないことから， 感染・発育に水温が与える影響も明らかにされていない。

\section{診断法}

本疾病の外観症状は魚種によって多少異なるが，頭骨 が浮き上がるほどの著しいやせ症状が 1 つの特徴である (Fig. $1 \mathrm{~A}$ and B)。解剖所見においては, 腸管が薄くな る，腸内に水様性内容物（腸水）が貯留するなどの症状 が見られる。トラフグやヤイトハタでは胆管閉塞や緑肝 も観察される。ヒラメでは，腹部膨満や脱腸も見られる。 E. leei とS. fugu の最も簡便な検出法は, 腸粘膜のスタン プ標本を作成し Diff-Quik 染色を施すことである。ただ し, E. leei はトラフグやヒラメではほとんど胞子を形成 しないため，スタンプ標本で観察されるのは径 10-20 $\mu \mathrm{m}$ の多核の栄養体である (Fig. 2 A and B)。S.fugu で は胞子も確認されるが，栄養体しか観察されないことも ある（Fig. 2D）。トラフグにおいては腸管内に複数種の 粘液胞子虫が混合感染するうえ, 栄養体は発育ステージ によって形態を変化させる。そのため, 簡便で迅速な診 断が可能ではあるものの, スタンプ法による種鑑別には ある程度の経験を要する。そのため, 特にトラフグにお いては後述する PCR 法の有用性が高い。組織学的には, E. leei と S. fugu ともに上皮組織内に多数の寄生体が観察 される。組織切片上で 2 種を形態的に鑑別するのは困難 だが，キチン質と結合する蛍光色素である Uvitex 2Bに 対してE. leei のみが陽性を示すことで見分ける事ができ る（Fig. 3）。Uvitex 2B 染色は，通常の HE 染色の前に Uvitex 2B を 1 \%濃度でPBSに溶解した染色液により10 分間行い，紫外光で観察する。

顕微鏡観察に代わる診断法としては, E. leei と S. fugu を特異的に検出する PCR 法が確立されている（Yanagida et al., 2005)。本法はスタンプ法に比べて検出感度が高 く，確実に種鑑別が可能である。PCR 法では，綿棒を肛 門に挿入して採集した腸内容物を DNA 抽出の材料とす ることで，魚を殺さずに検査することもできる（Fig. 4）。

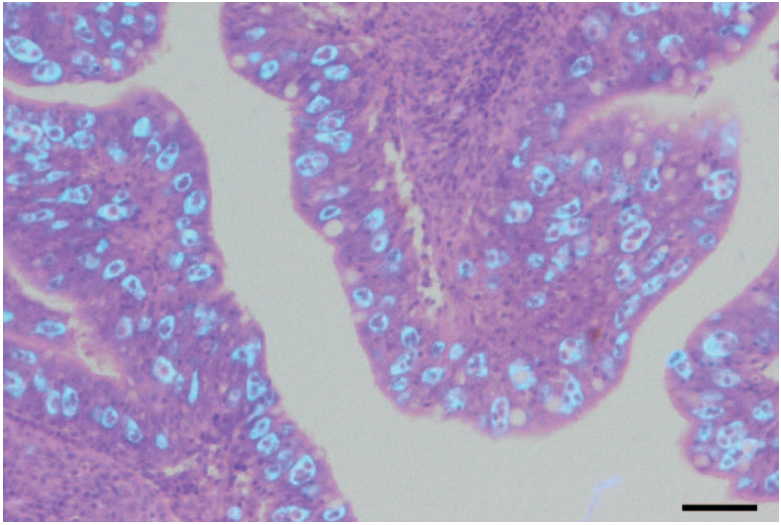

Fig. 3. Histological section of the intestine of red sea bream stained with Uvitex 2B - H\&E. Developmental stages of Enteromyxum leei are fluorescent in the epithelium of the intestine. Bar $=30 \mu \mathrm{m}$.

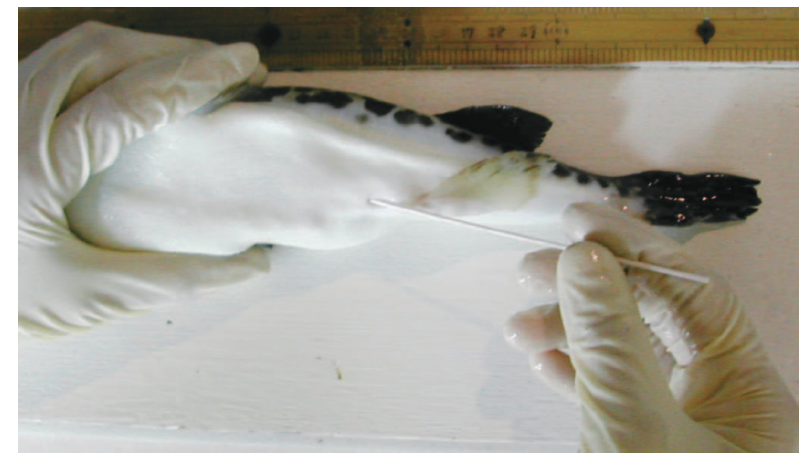

Fig. 4. Rectal examination of tiger puffer for the PCR detection using non-lethal sampling method.

さらに最近，より簡便で迅速な診断法として， LAMP 法も開発されている（堅田・奥山，2017）。本法は前述 の PCR 法よりも検出感度が高く, 3 時間程度で結果が 判定できるため, 今後，現場で応用されるかもしれない。

\section{防 除・予 防}

本疾病に対する治療法や防除法は確立されていない。 ヨーロッパでは, E.leeiに感染したシャープスナウト シーブリームに抗コクシジウム薬のアンプロリウムとサ リノマイシンを併用したところ, 虫体の変性が確認され, 感染率，感染強度ならびに致死率が有意に低下したとの 報告がある（Golomazou et al., 2006）ものの，未だ寒用 化には至っていない。他にも種々の薬剤や飼料添加物が 試されているが，本疾病を根治するものは見つかってい ない (Sitjá-Bobadilla and Palenzuela, 2012)。そのため, 本疾病への対策は予防を中心としたものにならざるをえ ない。

現状では，海面養殖において本疾病の感染を確実に防 ぐ方法はない。本疾病に限ったことではないが，種苗や 中間魚の導入時に PCR 法による検査を行うなど，まず 
は感染魚を漁場に入れないことが重要である。実際に, 以前筆者が行った調査では，感染したトラフグ種苗が漁 場に導入された例を確認している。E.leei は魚から魚へ 直接伝播するため, 養殖場内で速やかに感染が拡がりう る。そのため, 定期的な検査により感染魚を早期に発見 することも重要である。病魚や死魚を積極的に取り上げ て廃裹することで流行の抑制に慗がったと考えられる例 も報告されている（堅田ら，2015；Sitjá-Bobadilla and Palenzuela, 2012)。トラフグ養殖においては，種苗を 1 歳魚と離して導入することも感染予防になるかもしれな い。ただし，E.leei は海水中で24時間は感染性を保つた め, 伝播を防ぐためにどの程度の距離が必要かは今後明 らかにする必要がある。

陸上養殖であれば，飼育水を管理することで粘液胞子 虫の侵入を防ぐことが重要である。複数種のクドア属粘 液胞子虫において, 飼育水の紫外線処理による防除効果 が示されており (Shirakashi et al., 2014), 本疾病に対し ても効果が期待できる。また，E.leei の栄養体を 1/4 海 水で 1 時間処理することで感染性が減少したとの報告も ある（Yokoyama and Shirakashi, 2007）。魚体内の虫体 への効果はないと思われるが，一定期間の低塩分濃度飼 育によって再感染や他個体への伝播を抑制すれば, E. leei による本疾病の発生を抑えることができるかもしれない。 飼育水を取水する海域を污染しないためには，飼育排水 の処理も重要である。紫外線やオゾンで処理することが 考えられるが，効果的な照射量や濃度については検討が 必要である。

\section{最近の研究動向・残された課題}

本疾病への対策を確立するうえで残された課題は多い。 まず，本疾病の防除を効果的に実施するためにも，交互 宿主や天然魚の関与も含めた感染環の解明が望まれる。 これについては, 種特異的な PCR 法を用いるなどして 地道な調査を続けるしかない。治療法については, 実験 的に本疾病による死亡率を下げる効果が見られる薬剤も 報告されている（Sitjá-Bobadilla and Palenzuela, 2012）。 今後は，魚への副作用やコスト面も勘案しつつ，実用化 へ向けた検討を進めることが必要であろう。近年, ヨー ロッパでは E. leei や E. scophthalmi の感染に対する宿主 の免疫応答に関する研究が進められている。再感染に対 する抵抗性を獲得したと考えられる現象や，E.leei に感 染したヨーロッパヘダイでは虫体に特異的な抗体が産生 されたとの報告もあり（Sitjá-Bobadilla and Palenzuela, 2012), 将来的にはワクチンの開発が期待される。また, 本疾病の原因粘液胞子虫と宿主の相互関係を分子レベル で理解することは，耐病性種苗の作出や，効果的な飭料 添加物の発見にも繋がると思われる。既にトラフグやヒ ラメのゲノム情報は利用可能だが，今後E.leei を含む粘
液胞子虫についても飛躍的にゲノム情報の解明が進むと 考えられる。膨大なデー夕を有効に活用することで，近 い将来本疾病への対策が確立されることを期待したい。

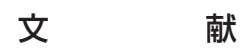

Alvarez-Pellitero, P., O. Palenzuela and A. Sitjà-Bobadilla (2008): Histopathology and cellular response in Enteromyxum leei (Myxozoa) infections of Diplodus puntazzo (Teleostei). Parasitol. Int., 57, 110-120.

知名真智子 - 中村博幸 - 濱川 薰 - 玉城英信 $\cdot$ 三輪 理 - 孟 飛・横山 博（2013）：養殖ヤイトハ夕に発生した粘液胞 子虫性やせ病. 魚病研究, 48, 88-96.

Golomazou, E., F. Athanassopoulou, E. Karagouni, S. Vagianou, H. Tsantilas and D. Karamanis (2006): Efficacy and toxicity of oral administrated anti-coccidial drug treatment on Enteromyxum leei infections in sharpsnout seabream (Diplodus puntazzo C.). Isr. J. Aquacult-Bamid., 58 157-169.

Gunter, N. and R. Adlard (2010): The demise of Leptotheca Thélohan, 1895 (Myxozoa: Myxosporea: Ceratomyxidae) and assignment of its species to Ceratomyxa Thélohan, 1892 (Myxosporea: Ceratomyxidae), Ellipsomyxa Køie, 2003 (Myxosporea: Ceratomyxidae), Myxobolus Bütschli, 1882 and Sphaerospora Thélohan, 1892 (Myxosporea: Sphaerosporidae). Syst. Parasitol., 75, 81-104.

Ishimatsu, A., M. Hayashi, M. Nakane and M. Sameshima (2007): Pathophysiology of cultured tiger puffer Takifugu rubripes suffering from the myxosporean emaciation disease. Fish Pathol., 42, 211-217.

堅田昌英・奥山芳生・小久保友義・中西 一 (2015)：養殖卜ラ フグとマダイにおける粘液胞子虫性やせ病原因虫の検出状 況. 魚病研究, 50, 127-129.

堅田昌英・奥山芳生（2017）：粘液胞子虫性やせ病原因虫の検出 に用いる LAMP 法の開発. 魚病研究， 52, 104-107.

Sekiya, M., A. Setsuda, H. Sato, K. Song, J. K. Han, G. J. Kim and I. K. Yeo (2016): Enteromyxum leei (Myxosporea: Bivalvulida) as the cause of myxosporean emaciation disease of farmed olive flounders (Paralichthys olivaceus) and a turbot (Scophthalmus maximus) on Jeju Island, Korea. Parasitol. Res., 115, 4229-4237.

Shirakashi, S., T. Nishimura, N. Kameshima, H. Yamashita, H. Ishitani, K. Ishimaru and H. Yokoyama (2014): Effectiveness of ultraviolet irradiation of seawater for the prevention of Kudoa yasunagai and Kudoa amamiensis (Myxozoa: Multivalvulida) infections in Seriola fish. Fish Pathol., 49, $141-144$

Sitjà-Bobadilla, A. and O. Palenzuela (2012): Enteromyxum species. In "Fish parasites: pathobiology and protection" (ed. by P. T. K. Woo and K. Buchman). CAB International, Oxfordshire, UK, pp. 163-176.

Tin Tun, K. Ogawa and H. Wakabayashi (2002): Pathological changes induced by three myxosporeans in the intestine of cultured tiger puffer, Takifugu rubripes (Temminck and Schlegel). J. Fish Dis., 25, 63-72.

Yanagida, T., Y. Nomura, T. Kimura, Y. Fukuda, H. Yokoyama and K. Ogawa (2004): Molecular and morphological redescriptions of enteric myxozoans, Enteromyxum leei (formerly Myxidium sp. TP) and Enteromyxum fugu comb. n. (syn. Myxidium fugu) from cultured tiger puffer. Fish Pathol., 
$39,137-143$.

Yanagida, T., M. A. Freeman, Y. Nomura, I. Takami, Y. Sugihara, H. Yokoyama and K. Ogawa (2005): Development of a PCR-based method for the detection of enteric myxozoans causing the emaciation disease of cultured tiger puffer. Fish Pathol., 40, 23-28.

Yanagida, T., M. Sameshima, H. Nasu, H. Yokoyama and K. Ogawa (2006): Temperature effects on the development of Enteromyxum spp. (Myxozoa) in experimentally infected tiger puffer, Takifugu rubripes (Temminck \& Schlegel). J. Fish Dis., 29, 561-567.

Yanagida, T., O. Palenzuela, T. Hirae, S. Tanaka, H. Yokoyama and K. Ogawa (2008): Myxosporean emaciation disease of cultured red sea bream Pagrus major and spotted knifejaw Oplegnathus punctatus. Fish Pathol., 43, 45-48.

Yasuda, H., T. Ooyama, K. Iwata, Tin Tun, H. Yokoyama and K.
Ogawa (2002): Fish-to-fish transmission of Myxidium spp. (Myxozoa) in cultured tiger puffer suffering from emaciation disease. Fish Pathol., 37, 29-33.

Yasuda, H., T. Ooyama, A. Nakamura, K. Iwata, O. Palenzuela and $\mathrm{H}$. Yokoyama (2005): Occurrence of the myxosporean emaciation disease caused by Enteromyxum leei in cultured Japanese flounder Paralichthys olivaceus. Fish Pathol., 40, 175-180.

Yokoyama, H. and S. Shikarashi (2007): Evaluation of hyposalinity treatment on infection with Enteromyxum leei (Myxozoa) using anemonefish Amphiprion spp. as experimental host. Bull. Eur. Ass. Fish Pathol., 27, 74-78.

Yokoyama, H., M. Kageyama, T. Yanagida and K. Ogawa (2009): Seawater survival of Enteromyxum leei (Myxozoa) evaluated by in vitro viability and in vivo infectivity assays. Fish Pathol., 44, 172-177. 